\title{
The influence of Internet in the Increased Suicides among Young Male Homosexuals
}

\author{
Marcelo Pombo Novaes Fernandes \\ ISCTE - IUL
}

\begin{abstract}
The figures on suicide among young people have been increasing in most countries around the world, specially among LGBTI people. Some researches show that a gay man has 5 to 11 times more possibility to commit suicide than a heterosexual of the same gender and age. The study we are working on tries to understand why it has been increasing and the influence of social midia on that.
\end{abstract}

Keywords: homosexuality, suicide, internet

\section{Problem}

According to sociological and medical studies, the number of suicides among young gay men traditionally very high - has ben in the rise since the beginning of the third millennium. This study aims to find out if there is a correlation between the popularization of internet and this phenomenon.

\section{Questions already answered:}

\section{What is a suicide?}

When the person decides to end his or her own life

That sounds a very simple question, but how can I define what are the limits of that?

Definition:

$\underline{\text { Suicide constitutes all cases of death directly or inderectly resulting from an act of a person who is }}$ aware of the consequences of such behaviour.

\section{What are the causes?}

Two main causes:

$>\quad$ Organic-psychologycal situation of the individual

(40\% of schizofrenic commit suicide 
20-22 March, 2020

Berlin, Germany $10^{\text {th }}$ International Conference on

Humanities, Psychology \& Social Sciences

In France, schizofrenic commit suicide 16x more than general people

Borderline Psychological Disorder, commit suicide 50x more than general people - Current Psychiatry Archives - 2009))

Borderline $-1,7 \%$ to $6 \%$ of the population

$>\quad$ The environment:

1. $60 \%$ of suicides happen during spring and summer. $40 \%$ in the rest of the year, from monday to thursday, from $6 a \mathrm{~m}$ to $4 \mathrm{pm}$.

2. Protestants are 3 times more probable to end their lives than Catholics or Jews.

3. They are much more common among men ( 4 men for 1 woman). Only 5 countries more women commit suicide than men

4. Last century, the highest number of suicides was among people over 70 years of age. Nowadays it is from 15 to 24 .

5. A married man with children has 2,9 times less probability of commiting suicide

6. The bigger the family, the fewer suicides.

7. It is inconclusive, but all researches seem to show that people that life in rich countries are more probable to commit suicide. 183 countries were analysed by the World Health Organization. Among the top 20 with highest figures, 13 were from Europe. Among the bottom 50 (fewer suicides), only 1 European: Greece.

\section{World Health Organization}

The WHO reports that, of its 172 Member States for which suicide estimates are published, only 60 have good-quality vital registration data that can be used directly to estimate suicide rates. They estimated suicide rates for the other 112 Member States.

Three statements accepted by the majority of the Academia (as first stated by Emilie Dukenhein):

1. As more religious the person, less suicide

2. As more integrated inside their families, less suicide

3. As more integrated into the society, less suicide

\section{Is suicide a taboo?}

Historically, we often look at the Victorian era in the later nineteenth century as a time when public discussion of sex was considered "taboo"; for much of the twentieth century, some argue, death replaced sex as the great taboo operating in our culture.

Throughout the centuries, for religious and moral reasons, suicide was considered one of the worst sins, perhaps the worst that a human being could commit. Suicide has been considered as something sinful.

In 2012, according to the World Health Organization, 804,000 people in the world died this way and, every year, the number of suicides is higher than that of homicides and war casualties 


\section{HPSCONF}

20-22 March, 2020

\section{Berlin, Germany}

$10^{\text {th }}$ International Conference on

Humanities, Psychology \& Social Sciences

combined. A person commits suicide every 40 seconds.

\section{Is there such a thing like right to live... right to die?}

If one had a right to live, then one must have the right to die, both on their terms.

Death is a natural process of life thus there should not be any laws to prevent it if the patient seeks to end it.

What we do at the end of our lives should not be of concern to others (or should it?).

\section{Is there still such a thing like homophobia?}

Acoording to professor L. Mosse, the ideal of masculinity has been evoked to preserve society againg the evils of modernity. Anything that is against this ideal of masculinity, virile and heterosexual, should be considered unnatural and therefore exterminated.

In a society based in the role differences for men and women headedby religion, the biggest example of abnormality and rebelion to rules (civil or God's) has to the the homosexuals.

By the end of XIX century to the beginning of XX, the Medicine takes from Religion the precedence of differring Normal from Abnormal, things didn't get any better. Even the father of Modern Sexuality, the psychiatric Kraft-Ebing, influenced by what we believe was the Zeitgest of that era, declared that "the degeneration derivated from homosexuality brings tension to society, leading families and all nation to decay".

From the religious concept of abomination, they started being labeled insane, sick or perverted. In other words, Medicine criminalize homosexuality and gives to secular Governments back up to persecute and condemn that social group. Such nonsense lasted until 1990, when finally the World Health Organization withdrew homosexuality from its list of mental diseases.

The burden is still around, very much alive on the shoulders of all homosexuals, but it is havier on the young ones. Even in countries that are considered more tolerant, we can not state that they have a life we could declare as easy or normal.

In Portugal, for exemple, research financed by the Comissão para a Cidadania e Igualdade de Gênero states that homossexuals have sufferred, during their lives, physical or verbal abuse - and the Christianism was considered by them as the main source of discrimination.

Still in Portugal, a research developed by PUC-RS University from Brazil, in 2019, among the students of Ciences of Education - University of Coimbra (with 108 students interviewed), showed threatning results: 


\section{HPSCONF}

\section{0-22 March, 2020}

\section{Berlin, Germany}

$10^{\text {th }}$ International Conference on Humanities, Psychology \& Social Sciences

a) a total of $63,9 \%$ considered possible to change sexual orientation

b) for $43,5 \%$ see homosexuality as illness and abnormal

c) for $50 \%$, homosexuality is a choice

d) homosexuality is a result of a trauma during childhood, for $94,4 \%$

e) as more homosexual talking, as more easily people 'become' homosexuals, for $90,7 \%$

\section{Are young homosexuals more probable to commit suicide?}

As for the EUA, another research, devolep by Columbia University among 32.000 youngsters with ages varying from 13 to 17 got the conclusion that a homosexual commit suicide is 5 times more probable than a young heterosexual.

The Suicide Prevention Resource Center, one of the most reputable american NGOs says that $30 \%$ to $40 \%$ of all homosexuals try to end their lives during their existence. Brazilian NGOs say that the number of victims among homosexuals are 8 times higher than the Brazilian average (32 in every 100 thousand per year, comparing to an average figure of 4 in each 100 thousand - among non homosexuals).

\section{Is Internet harmful for the young ones?}

According to the North-American psychologist Jean Twenge (for the Clinical Psychological Science Maganize), teens who spent five or more hours a day online were $71 \%$ more likely than those who spent less than an hour a day to have at least one suicide risk factor (depression, thinking about suicide, making a suicide plan or attempting suicide).

"Interacting with people face to face is one of the deepest wellsprings of human happiness; without it, our moods start to suffer and depression often follows. Feeling socially isolated is also one of the major risk factors for suicide. We found that teens who spent more time than average online and less time than average with friends in person were the most likely to be depressed ."

Another study led by University of Pittsburgh and presented by BBC, states that spending two hours a day in one or more social networks such as Faceboo, Twitter or Snapchat, duplicates the possibility of feeling isolated. That is the solitude among the multitude. Another research, led by ISPA in Portugal and published by Observador, claims that $25 \%$ of all young Portuguese are addicted to Technology.

According to the Royal Society for Public Health, those social networks are associated to several different forms of mental illnesses, such as anxiety, depression an bullying. According to their studies, Istagram is on top of all the mischievous plataforms. 


\section{HPSCONF}

20-22 March, 2020

Berlin, Germany $10^{\text {th }}$ International Conference on Humanities, Psychology \& Social Sciences

The emergence of a new mental illness, FOMO (fear of missing out), has been added to the long list of psychologycal disorders. The fear of loosing information, relevance, rewarding experiences... the fear of being irrelevant or forgotten... the eternal anxiety for approval, being constantly under the pressure of being evaluated.

According to the child psychiatrist Timothy Wilens, from Massachusetts General Hospital (EUA), as published in the Journal of the American Academy of Child and Adolescent Psychiatry, "During this period (the childhood) there is an inscrease in the emotional excesses that are followed by little capacity of discernment".

In the same path, the specialist in mental health from Unicamp / Brasil, doctor Neury Botega, the teen brain in not fully prepared for such pressure. Their brains haven't had enough time to build a system do deal with so many pushes. That asymmetry in their brains, according to him and to other cientists, make the brain more psychologicaly fragile, more susceptible to anxiety, panic syndrome and depression. Those mental imbalance may become trigers to suicide.

\section{Questions to be answered:}

We have got quite a rich range of books wich covers the phenomenon of suicide and its main causes. We also have many researches about suicides among LGBTI+ people and main reasons for such radical act. Psychologysts, Psychiatrists, Social Educators and even some Anthropologists are dealing with the influence of Internet and Social Networks on the young one's lives.

The answer still to be answered is the main reason for this work:

1. Is there a connection between the increase in suicides among gay people related to their use of Internet? What is the influence of the Digital World on it (assuming there is some)?

We are conscious of the fact that:

I. The connection between LGBTI+ people and suicide has been studied

II. The connection between Internet and suicide has just started been on stage

III. There is very little material on the influence of Internet among LGBTI+ people

The focal point of our study will be to connect these 3 subjects: Male Homosexuals + suicide rates + internet influence. And that hasn't been done so far.

\section{Methodology:}

A questionnaire will be handed out among young male homosexuals (ages varying from 13 to 25) in order to collect some data.

We aim to know:

$x$ How many have ever had suicidal thoughts

$x$ How many are dealing with suicidal thoughts

$x$ How many have already tried to commit suicide

× What are their moral values related to suicide 


\section{HPSCONF}

20-22 March, 2020

Berlin, Germany $10^{\text {th }}$ International Conference on Humanities, Psychology \& Social Sciences

$x$ How many hours a day they use internet (try to confirm if those that are more linked to Internet are more at risk)

$x$ What are their favourite digital plataforms

$\boldsymbol{x}$ Their impressions about the main digital plataforms

The field: young male homosexuals (13 to 25 y.o.) that use the internet in Brazil and Portugal. They will be contacted on line (from gay digital pages) and invited to answer the questionnaire.

\section{State of Art / Bibliography}

Abram, David. A Magia do Sensível. Percepção e Linguagem num mundo mais do que humano, Fundação Calouste Gulbenkian, Lisboa. 2007.

American Anthropological Association Executive Board (AAA), Statement on Human Rights (submitted to the United Nations Commission on Human Rights). 1947.

Bauman, Zygmunt. Liquid Modernity, Cambridge, Polity Press. 2000.

Borrillo, Daniel. Homofobia: história e crítica de um preconceito. Autêntica Editora, Belo Horizonte - Brasil, 2010

Bozon, M. Sociologia da sexualidade, Rio de Janeiro, FGV, 2004.

Breuning, Loretta G. Habits of a Happy Brain. New York: Simon \& Schuster. 2015.

Bulmer, Martin, \& Anthony M Rees. Citizesnhip Today . UCL Press, London, 1996.

Cury, Augusto. Ansiedade: como enfrentar o mal do século: a Síndrome do pensamento Acelerado: como e porque a humanidade adoeceu coletivamente, das crianças aos adultos. São Paulo: Saraiva. 2014. 1989.

Dawkins, Richard. The Selfish Gene. 2nd ed. United Kingdom: Oxford University Press.

Durkheim, Emile. O Suicídio - Estudo Sociológico. 10 ed. Editorial Presença, Lisboa, 2019.

Escobar, Arturo. 2018. Designs for the Pluriverse. Radical Interdependence, Autonomy, and the Making of Worlds, Durham and London: Duke University Press

Evans, David. Sexual Citizenship. Routledge, London, 1993.

Freud, Sigmund. Três ensaios sobre a teoria da Sexualidade. São Paulo, Companhia das Letras, 2016

Giddens, Anthony. The Transformation of Intimacy. Polity Press, Oxford, 1992. 
20-22 March, 2020

Berlin, Germany

\section{$10^{\text {th }}$ International Conference on Humanities, Psychology \& Social Sciences}

Harari, Yuval Noah. Homo Deus, uma breve história do amanhã. São Paulo: Companhia das Letras, 2016.

Harari, Yuval Noah. Sapiens: Uma breve história da humanidade. São Paulo: L\&PM Editores, 2015.

Ingold, Tim. Who studies humanity?: The scope of Anthropology, Anthropology Today, Vol. $1, n^{\circ} 6.2015$.

Machado, Maria das Dores C \& Fernanda D Piccolo. Religiões e homossexualidade. FGV, Rio de Janeiro, 2010

Miller, Daniel. Tales from Facebook. Cambridge Press, Cambridge, 2013.

Mosse, George L. Nationalism and Sexuality. Editora Howard Fertig, New York, 1985.

Naphy, William. Born to be gay. Edições 70, Lisboa, 2006

Nowland, R., Necka, E.A. \& Cacioppo, J.T. Loneliness and social internet use: Pathways to reconnection in a digital world? Perspectives on Psychological Science. Journal of the Association for Psychological Science, 2017.

Plummer, Ken. Inventing Intimate Citizenship.University of Washington Press, 2003. 1998.

Robbins, Paul R. Adolescent Suicide. McFarland \& Company, Jefferson - North Carolina,

Rodrigues, JC. Brincando de deus - Criação mundos virtuais e experiências de imersão digitais. Rio de Janeiro: Marsupial Editora. 2016.

Schmidt, Eric \& Jared Cohen. A nova era digital: como será o futuro das pessoas, das nações e dos negócios. Rio de Janeiro: Intrínseca. 2013.

Silva, Ana Cristina Kamburova. Identidade em pixels: a fotografia e a apresentação do eu no Instagram - Dissertação de mestrado . ISCTE-IUL, Lisboa. 2015.

Silva, A.N.N. Homossexualismo e discriminação: o preconceito sexual internalizado. Tese (Doutorado) - PUC-Rio, Rio de Janeiro, 2007

Toren, Christina, Anthropology as the Whole Science of What it is to Be Human, Berg: B King, 2012.

Twenge, Jean M. Why Today's Super-Connected Kids Are Growing Up Less Rebellious, More Tolerant, Less Happy--and Completely Unprepared for Adulthood--and What That Means for the Rest of Us. New York, NY : Atria Paperback, 2018.

Ward, Peter. Future Evolution, EUA: W. H. Freeman. 2001. 


\section{HPSCONF}

\section{0-22 March, 2020}

\section{Berlin, Germany}

$10^{\text {th }}$ International Conference on Humanities, Psychology \& Social Sciences

Aditional Bibliography

http://revistaseletronicas.pucrs.br/ojs/index.php/porescrito/article/view/31786/17592

https://dezanove.pt/homossexualidade-ou-como-ser-um-cidadao-847877

https://www.cmjornal.pt/sociedade/detalhe/portugal-e-dos-paises-que-mais-protege-oshomossexuais

https://super.abril.com.br/comportamento/gay-tambem-e-cidadao/

https://psifocus.blogspot.com/2019/02/a-dor-de-nao-pertencer.html

http://www.dn.pt/portugal/interior/e-na-religiao-que-os-homossexuais-sesentem-maisdiscriminados-1571679.html

http://revistagalileu.globo.com/Revista/Common/0,EMI22680617770,00JOVENS+HOMOSSE XUAIS+TEM+MAIS+TENDENCIA+AO+SUICIDIO+ DIZ+ESTUDO.html

https://www.publico.pt/2018/07/09/culto/noticia/reino-unido-proibe-terapias-de-reorientacaosexual-1837145

http://www.naozero.com.br/antropologia-digital

http://www.revistas.uff.br/index.php/antropolitica

https://blogs.ne10.uol.com.br/mundobit/2015/10/15/antes-dos-snaps-uma-breve-historia-dosnudes-na-internet/

https://depts.washington.edu/hhwb/Thm_Mental.html

https://journals.openedition.org/etnografica/3168

https://observador.pt/especiais/solidao-na-era-digital-nunca-estivemos-tao-conectados-e-tao-sos/ https://psychcentral.com/lib/proximity-to-green-spaces-boosts-health/

https://rr.sapo.pt/noticia/126109/papa-aborda-a-natureza-das-relacoes-na-internet-emmensagem-sobre-comunicacoes-socais

https://tecfront.blogosfera.uol.com.br/2018/08/29/como-a-internet-esta-reinventando-a-solidao/ https://veja.abril.com.br/saude/a-tragedia-do-suicidio-entre-jovens-taxas-nunca-foram-tao-altas/ https://wearesocial.com/uk/blog/2018/01/global-digital-report-2018 


\section{HPSCONF}

20-22 March, 2020

Berlin, Germany $10^{\text {th }}$ International Conference on Humanities, Psychology \& Social Sciences

https://www.academia.edu/35874047/A_TEORIA_DA_ANTROPOLOGIA_DIGITAL_PARA_ AS_HUMANIDADES_DIGITAIS

https://www.dn.pt/sociedade/interior/vicio-da-internet-ja-atinge-25-dos-jovens-5783779.html

https://www.jahonline.org/article/S1054-139X(14)00307-3/fulltext

https://www.jn.pt/mundo/interior/mais-pornografia-menos-sexo-assim-e-a-vida-dos-millennials10080649.html

https://www.jn.pt/nacional/saude/interior/uso-problematico-da-internet-associado-a-ansiedadee-depressao-4523571.html

https://www.megacurioso.com.br/ciencia/85425-10-beneficios-que-o-contato-com-a-naturezatraz-para-a-sua-saude.htm

https://www.nature.com/siteindex

https://www.noticiasaominuto.com/lifestyle/1003561/o-instagram-e-a-pior-rede-social-para-asua-saude-mental

https://www.psychologicalscience.org/publications/observer/obsonline/lonely-people-usefacebook-more-does-more-facebook-make-you-lonelier.html

https://www.psychologytoday.com/us/blog/connected/201501/how-many-teens-are-actuallysexting

https://www.rsph.org.uk/about-us/news/instagram-ranked-worst-for-young-people-s-mentalhealth.html

https://www1.folha.uol.com.br/ilustrissima/2017/08/1907983-com-internet-cada-vez-maisjovens-sofrem-de-depressao-e-ansiedade.shtml 